Universidad de Guadalajara

DERECHO GLOBAL. ESTUDIOS SOBRE DERECHO Y JUSTICIA Año 2022, Vol. VII. Número 20, Marzo - Junio, ISSN: 2448-5128 e-ISSN: 2448-5136 https://DOI.org/ 10.32870/dgedj.v7i20.403

JOSÉ ALBERTO DEL RIVERO DEL RIVERO

Universidad Juárez Autónoma de Tabasco, México josealberto@delriveroasociados.mx

\title{
La Verdad Histórica, Sociológica Y Jurídica del Ayuntamiento Municipal DENTRO de LA NOCIÓN DEL FEderalisMo Mexicano
}

\section{ThE HistoricAL, SOCIOLOGICAL AND LEGAL TRUTH OF THE MUNICIPAL COUNCIL WITHIN THE NOTION OF MEXICAN FEDERALISM}

Cómo citar el artículo:

Del Rivero J, (2022). La Verdad Histórica, Sociológica y Jurídica del Ayuntamiento Municipal Dentro de la Noción del Federalismo Mexicano. Derecho Global, Estudios sobre Derecho $y$ Justicia, VII (20) https://DOI.org/ 10.32870/dgedj.v7i20.403 pp. 103-145

Recibido: 07/08/20 Aceptado: 03/02/21 


\title{
RESUMEN
}

La presente investigación tiene como objetivo principal dilucidar cómo se excluye a la esfera municipal a pesar de su valor dentro de la Historia de México, considerando que "sin Historia del Derecho, no hay Historia de la Civilización" (Levene, 1973, p. 8). Dicho contexto contradice el linaje histórico del municipio y, por ende, distorsiona las propuestas sustentadas durante el Congreso Constituyente de 1916-1917. Escenario que ha provocado en la práctica que se cometan invasiones a esta esfera por parte de la federación y los estados, asimismo, ha llevado a ubicar al gobierno municipal en una situación de vasallaje petrificado contraria a la evolución del constitucionalismo, principalmente por lo que atañe al principio de división de poderes.

\section{Palabras claves}

Ayuntamiento; gobierno; municipio; federalismo; división de poderes.

\begin{abstract}
The main purpose of this investigation is to explain how the municipal sphere is excluded despite its value within the History of Mexico, considering that "without History of Law, there is no History of Civilization" (Levene, 1973, p. 8). This context contradicts the historical lineage of the municipality and, therefore, distorts the proposals presented during the Constituent Congress of 1916-1917, a scenario that has led in practice to invasions against this sphere by the federation and the states, placing the municipal government in a petrified vassalage despite the evolution of constitutionalism, mainly regarding the principle of separation of powers.
\end{abstract}

\section{KeYwORDS}

Municipal council; government; municipality; federalism; separation of powers. 
Sumario: I. Introducción. II. Reflexiones en torno a la diferencia entre Municipio y Ayuntamiento. 1. Municipio. 2. Ayuntamiento. III. El Ayuntamiento como primera esfera histórica, sociológica y jurídica del Federalismo en México. IV. La exclusión Constitucional del Ayuntamiento como parte "no integrante" del pacto Federal en México. V. Conclusiones. Bibliografía.

\section{INTRODUCCIÓN}

Uno de los pilares que apuntalan el sistema político mexicano es el federalismo que jurídicamente fue adoptado a principios del Siglo XIX. El federalismo es una forma de Estado presente en países como Estados Unidos (EE.UU.), Alemania, Brasil y por supuesto México, entre otros. Cada uno posee características propias a su historia y al contexto en el que se originaron, pero en general se puede señalar que el federalismo se caracteriza por la unión política de diferentes entes territoriales regidos por sus propios gobiernos bajo un pacto político, que no pierden del todo su autonomía, ni su soberanía. En el caso de los E.E.U.U. su federalismo radica en la unión de estados soberanos que pactaron entre sí para crear, a su vez, una Federación y así lo establece claramente su constitución. En el caso de México, se tienen tres esferas constitucionales: Municipios, Estados y Federación, que como parte de un supuesto hipotético se encuentran unidos bajo un pacto, mas no de forma jurídica ni fáctica. Por dicha razón, unos resultan ser más autónomos y soberanos (que es el caso del gobierno Federal y los gobiernos Estatales), mientras que otros se han visto históricamente mermados en estos aspectos (el caso de los ayuntamientos). Este escenario ha ocasionado que esta esfera sea interpretada como un "tercer orden de gobierno", por debajo de los gobiernos estatales y el de la federación, de tal suerte que en la consignación constitucional se ha excluido a la misma como parte de un pacto federal tripartito. Cuando lo correcto es que el ayuntamiento representa histórica, sociológica y jurídicamente la primera esfera constitucional del federalismo en México. 
El anterior panorama ha provocado, inter alia, que los ayuntamientos de los municipios pierdan los poderes esenciales de las esferas constitucionales que integran la federación en México. Como es bien sabido, el gobierno federal se divide en tres poderes: legislativo, ejecutivo y judicial, ocurriendo lo mismo con los gobiernos estatales, sin omitir mencionar que estos son representados ante la federación a través de la figura del Senado. No obstante, los ayuntamientos no cuentan con órganos que ejerzan la justicia de paz como hubo en el pasado inmediato, ni tampoco los municipios o regiones tienen una figura como la del senado para su representación en la esfera estatal, que también la historia revela que en el Siglo XIX existió, como nos lo hace ver González Oropeza (citado en Ayllón González, 2010), tema que en líneas siguientes será retomado. Amén de ello, los poderes legislativo y ejecutivo del ayuntamiento presentan serias deficiencias derivadas de invasiones competenciales debido a la falta de una previsión constitucional que divida las funciones del poder político ejercido en el municipio, como ocurre en los sistemas de otros países federales.

Por ende, el sistema político mexicano ignora que el municipio es el núcleo de la sociedad y que la historia de la humanidad revela cómo el pueblo ejerce primero su soberanía a través de esta esfera, antes de ejercerla por conducto de los estados o de la federación, como infortunadamente establece el texto fundamental mexicano. La soberanía materializada en el gobierno municipal ha definido el rumbo de la historia en diversos momentos, permitiendo la transición entre distintos sistemas políticos. Esto ocurrió en el caso de la península ibérica, cuando la figura del ayuntamiento fungió como una herramienta política para terminar la organización feudal, transitando a la consolidación de reinos centralistas que, a su vez, utilizaron el ayuntamiento municipal para reconquistar las zonas ocupadas por los árabes (Rodríguez Mejía, 2002; Valencia Carmona, 2017), dotándolas de autonomía política. Asimismo, en la Francia revolucionaria, el gobierno municipal en forma de ayuntamiento, que reunía a las denominadas secciones como órganos de la vida municipal, fue una pieza clave. Este propició el 10 de agosto de 1792 el destronamiento del rey Luis XVI, dando inicio a un

\section{DERECHO GLOBAL. ESTUDIOS SOBRE DERECHO Y JUSTICIA}


movimiento que veía en ese día, no el coronamiento de la revolución originada en 1789, sino a su entendimiento, una "nueva revolución popular e igualitaria", por lo que como consecuencia en el gobierno municipal comenzó a incidir una nueva serie de deberes (Kropotkin, 2005, p. 281).

En el caso de México, el gobierno municipal ha demostrado que tiene propiamente "poder político" pese a que aún después de la consignación de 1917 del municipio libre en el artículo 115 constitucional, en la praxis política se sostuvo por casi un siglo que esta esfera, a diferencia de los estados y la federación, no contaba con dicho poder, demostrando así que sus funciones (que históricamente sirvieron para la organización territorial de nuestro país) fueron coartadas. La primera evidencia de ejercicio de la soberanía del pueblo a través del ayuntamiento en México se remonta al Siglo XVI (figura que legitimó a Hernán Cortés para llevar a cabo su conquista), estructura de gobierno que con el tiempo se conjugó con la organización territorial de los naturales. Recordando, además, que las primeras ordenanzas municipales fueron dictadas por Cortés en 1525 (Del Rivero del Rivero, 2017). De ahí que el ayuntamiento municipal preceda en tiempo a la esfera estatal y federal que jurídicamente se consolidaron a inicios del Siglo XIX. Incluso la historia demuestra que, ante la ausencia y en nombre del rey cautivo por la ocupación napoleónica en España, el entonces Ayuntamiento de la Ciudad de México entregó a la Audiencia de México el primer documento en 1808 que en la Nueva España sostuvo la tesis de la reasunción de la soberanía por el pueblo (Tena Ramírez, 1976). De igual forma, en pleno proceso de independencia, en los Elementos Constitucionales de 1812 escritos por Ignacio López Rayón, se establecía en el artículo 20 que los extranjeros que quisieran disfrutar de los privilegios de ciudadano americano debían impetrar carta de naturaleza a la Suprema Junta, siendo esta concedida con acuerdo del correspondiente ayuntamiento y disensión del Protector Nacional (Tena Ramírez, 1976), función que sin duda fortalecía esta esfera constitucional. 
Así pues, debe visionarse que el pueblo también ejerce su soberanía a través de la esfera municipal, pues en él recae el gobierno municipal, no entendido este solo como la función ejecutiva, sino como un todo, desechando así la noción de "órdenes de gobierno", ya que las tres esferas del pacto federal, no deberían supeditarse unas a otras, sino enlazarse de manera horizontal en una gobernanza (Del Rivero del Rivero, 2017). Pero, en su lugar, el sistema político mexicano parece ignorar que "la soberanía es a los pueblos lo que la libertad a los hombres" (Del Castillo Velasco citado por De la Cueva, 1948, p. 52), y lo que la autonomía es a los municipios. Atendiendo a ello, en la presente investigación se pretende argumentar la exclusión tanto normativa como fáctica de la esfera municipal fuera del pacto federal a pesar de su valor a lo largo de la historia de México. En aras de comprobar dicha hipótesis, la investigación se desarrolló en torno a un método basado en las ciencias jurídicas, en el que fue necesario recurrir a la hermenéutica de las fuentes del Derecho (formales, reales e históricas) en relación a este tema. En dicho tenor, este artículo parte primero de una explicación sobre el gobierno municipal (siendo para ello menester diferenciar entre las nociones de municipio y ayuntamiento), para así proceder con la argumentación sobre por qué el ayuntamiento municipal representa (antes que los estados y la federación) la primera esfera constitucional, y cómo, a pesar de esto, ha sido excluida constitucionalmente del pacto federal, tanto en lo concerniente al articulado del texto fundamental mexicano, como en los actos invasivos competenciales de autoridades.

\section{REFLEXIONES EN TORNO A LA DIFERENCIA ENTRE MUNICIPIO Y AYUNTAMIENTO}

Dentro de la academia y la enseñanza de las estructuras orgánicas que componen el sistema político mexicano, se tiende a confundir ciertos elementos e instituciones esenciales, como es el caso del municipio y del ayuntamiento. Por consiguiente, resulta imprescindible en esta investigación realizar un primer esbozo en cuanto a su diferenciación para después continuar con el análisis sobre

\section{DERECHO GLOBAL. ESTUDIOS SOBRE DERECHO Y JUSTICIA}


la exclusión que esta esfera constitucional ha tenido como parte no integrante del pacto federal.

\section{Municipio}

Todo municipio cuenta con una población, un territorio y una autoridad, y es del primer elemento de donde surge la naturaleza de dicho ente, puesto que allí se establecen relaciones de proximidad entre las personas, sosteniendo que "Sin la existencia de lo vecinal, no se comprende al municipio" (Elguera, 1997). En este orden de ideas, hay autores que señalan que su naturaleza ha acompañado al ser humano desde los orígenes de la civilización, con la formación de grupos primigenios (hordas, familias, clanes, tribus, confederaciones tribales); pasando por la Edad Antigua, con las sociedades asentadas en Mesopotamia, Egipto, así como la polis de la Antigua Grecia (Quintana Roldán, 2008). En este punto vale la pena aclarar, como señala Elguera (1997), que esta concepción del origen del municipio como derivado de la naturaleza gregaria de los seres humanos corresponde a la escuela sociológica o iusnaturalista que entiende al municipio como una institución del derecho natural que surge de manera espontánea por la cercanía entre las personas, y que es reconocido a posteriori por el Estado. Como contrapartida, se encuentra la escuela legalista o positivista cuyos defensores aducen que el municipio es una entidad territorial creada por el Derecho, siendo el Estado el que le otorga sus atribuciones, las amplía, reduce o en algunos casos las suprime (Elguera, 1997).

En aras de estudiar los orígenes del municipio, es importante considerar ambas escuelas, ya que son complementarias desde un punto de vista evolutivo, por lo que no están contrapuestas. Incluso hay autores que abogan por una "solución intermedia", entendiendo que se trata de dos aspectos distintos: por un lado, la "agrupación humana" como "hecho social" (en el sentido iusnaturalista) y, por otro lado, el municipio propiamente dicho como "institución jurídica" (positivista), pero que el primero representa los cimientos históricos del segundo 
(Valencia Carmona, 2002). Lo cierto es que el municipio se origina de forma natural, inconsciente, por la unión y proximidad entre habitantes y a la vez como un medio de protección comunitaria y subsistencia, así como para llevar a cabo de manera colectiva los fines que le son indispensables. De esta manera, dicha agrupación vecinal tiende a la complejidad y, por ende, debe institucionalizarse, adoptando ya la denominación político-jurídica de municipio (Del Rivero del Rivero, 1986).

En este sentido, partiendo ya desde una óptica positivista siguiendo a Cabanellas (1989a), la institucionalización propiamente del municipio ocurrió en la Antigua Roma con la aparición de las ciudades principales y libres que se regía por sus propias leyes y cuyos habitantes podían obtener y gozar de los derechos y privilegios de Roma. Elguera (1997) profundiza en el tema, señalando que lo anterior sucedió debido a la expansión romana y a la conquista de ciudades, las cuales se incorporaban a Roma, pero sin tener derechos políticos, debiendo pagar un tributo que recibía el nombre de municipia del latín munus — carga - Por su parte, Corominas y Pascual (1991) mencionan que la palabra municipia se refiere en general a todas aquellas ciudades que el Derecho Romano otorgaba la calidad de libres para su manejo administrativo, dicho término evolucionaría a la voz municipium. Palabra compuesta por dos locuciones, a saber, el sustantivo munus, que significa cargas, obligaciones, tareas y oficios, así como el verbo capere, que se traduce como "tomar", o "hacerse cargo de algo". Dichas ciudades eran sujetos de Derecho privado y estaban facultadas para adquirir bienes y contraer obligaciones (Elguera, 1997). De lo anterior se desprende que la denominación de municipio, desde su génesis en la Antigua Roma, se aplicaba a un territorio en específico, y no debe confundirse este con la estructura que lo gobierna, como se analizará a continuación. Es menester aclarar que, como derivado de lo anterior, también se acuñó la expresión "munícipes" que hacía referencia a los hombres libres nacidos en alguna ciudad sujeta al entonces Imperio Romano y que participaban con los ciudadanos de honores y de empleos (Ferrier, 2007).

\section{DERECHO GLOBAL. ESTUDIOS SOBRE DERECHO Y JUSTICIA}




\section{Ayuntamiento}

Como se desprende del apartado precedente, al hablar de municipio, se hace referencia al territorio, en el que también debe contarse con una estructura de poder que lo gobierne. Este andamiaje se denomina ayuntamiento, afirmación que se argumentará a lo largo de este inciso temático. El origen de esta estructura no se remonta a la Antigua Roma como el caso del municipio, sino que se sitúa entre los Siglos XI y XII, floreciendo a principios del Siglo XIII hasta inicios del Siglo XV, en su origen fue un aliado para los reyes en la lucha en contra del feudalismo, derivándose así la emancipación civil y política de los pueblos respecto de los señores feudales (Cabanellas, 1989b; Rodríguez Mejía, 2002). Pero también el origen de los ayuntamientos tiene, a su vez, un enlace indisoluble con la Reconquista de la península ibérica, ya que a partir del Siglo XI los monarcas católicos concedieron fueros a los municipios que estaban en manos de los árabes con el propósito de repoblarlos, exentándoles de cargas y mejorando las condiciones de vida de sus habitantes, de tal manera que el municipio se desenvolvía con base en el concilium que consistía en una asamblea general de vecinos (cabildo abierto), que más tarde fue sustituida por un cabildo cerrado o ayuntamiento (Valencia Carmona, 2017). Con ello se comprende que el ayuntamiento surgió como una estructura de poder delimitada a un territorio, entiéndase municipio, no debiendo confundirse la una con la otra.

Aunado al anterior trasfondo histórico, se encuentra la necesidad de aclarar dos aspectos: 1) que no solo la noción de Estado como un todo se encuentra regida por un gobierno, sino también los municipios tienen sus gobiernos a través del ayuntamiento; y 2) que la noción de gobierno no solo se limita al grupo de funcionarios que ejercen el poder ejecutivo. En cuanto al primer punto, Cabanellas (1989c) señala que un gobierno es un "Orden, régimen o sistema para regir la nación o alguna de sus regiones, provincias o municipios” (p. 181). En relación al segundo aspecto, Burgoa (2003) define que, desde una óptica orgánica, el gobierno se conforma por el conjunto de autoridades de un Estado, 
no limitándose solo a las administrativas, sino también a las legislativas y judiciales, ya que, en palabras de este autor, "indebidamente y por una corruptela tradicional e histórica, el gobierno se ha identificado con los órganos del Estado en que se deposita el poder ejecutivo, excluyéndose a los otros dos tipos" (p. 207). Apoyando esta tesis, Castagno (1997) expone una serie de acepciones sobre el vocablo gobierno, y citando a Xifra Heras, señala que el gobierno es "el conjunto de órganos encargados del ejercicio del poder público", aclarando que "corrientemente se llama también Gobierno al órgano preeminentemente del mal llamado Poder Ejecutivo" (p. 310). Como contrapartida, Levi (1981) explica que el gobierno, desde una primera aproximación, se refiere al "conjunto de las personas que ejercen el poder político" (p. 743). Sin embargo, posteriormente aclara que, en relación con las funciones del Estado, el concepto de gobierno coincide con el poder ejecutivo, señalando que los órganos legislativos y judiciales no forman parte directamente de los órganos de gobierno, lo cual para dicho autor no implica que estos últimos no puedan delimitar y controlar en cierto modo la acción de gobierno (Levi, 1981). En esta investigación se coincide con el criterio de Burgoa (2003), Castagno (1997) y parcialmente con Levi (1981), puesto que el gobierno, entendido como un todo, es la forma en que se materializa y ejerce el poder político sobre un territorio en específico. Poder que, para una mayor eficacia y contar con frenos y contrapesos, se divide en tres funciones, mas todas ellas se subsumen dentro de la noción de gobierno. En realidad, cuando se habla de las diferentes "formas de gobierno" que existen en el mundo, se hace referencia a la manera en que se encuentra estructurado el poder político de un Estado, como un todo, que en nuestro caso la Constitución Política de los Estados Unidos Mexicanos (CPEUM) establece que el supremo poder se divide para su ejercicio en un poder legislativo, ejecutivo y judicial. De este modo, la postura que señala que el gobierno es sinónimo del poder ejecutivo corresponde a una mala interpretación que margina a los otros dos poderes del Estado, provocando una deficiente gobernabilidad y, por consiguiente, gobernanza.

\section{DERECHO GLOBAL. ESTUDIOS SOBRE DERECHO Y JUSTICIA}


Lo anterior resulta fundamental en esta investigación en razón de que, como se abordará infra, un verdadero federalismo respetaría la estructura del poder político (dividida para su ejercicio en sus tres funciones) de cada esfera constitucional que lo integra, lo que no sucede con los ayuntamientos de los municipios en México, esferas que se han visto mutiladas históricamente en las tres funciones en que se debería claramente dividir su poder político. Por consiguiente, desde una primera aproximación normativa, este panorama contraviene lo establecido por el artículo 115 de la CPEUM que señala: "Cada Municipio será gobernado por un Ayuntamiento", comprendiendo que el poder político de un gobierno debe dividirse para su ejercicio en los poderes legislativo, ejecutivo y judicial. Empero, la praxis política de nuestro país ha dictado que gobierno es llanamente un sinónimo de los titulares de los poderes ejecutivos de cada esfera constitucional, quienes en realidad acometen una función administrativa dentro de los gobiernos. Sobre este tema, resultan valiosas las palabras del publicista francés decimonónico, Ducroq, quien aseguraba que "el gobierno es la cabeza y la administración es el brazo" (Citado en Valencia Carmona, 2002, p. 29). Precisamente la importancia de la división de funciones en la esfera municipal es un tema neurálgico a lo largo de este artículo para comprender cuáles figuras municipales son depositarias de cada poder. De momento, debe quedar claro entonces que el ayuntamiento es una estructura de poder circunscrita a un ámbito territorial, o sea, el municipio, ya que es este último en donde el ayuntamiento ejerce su jurisdicción.

\section{El Ayuntamiento como primera esfera histórica, SOCIOLÓgICA Y JURÍdICA DEL FEDERALISMO EN MÉXICO}

Si bien el federalismo fue adoptado oficialmente como forma de estado en primer lugar por los EE.UU. en el Siglo XVIII, la génesis del federalismo mexicano es aún más antigua que la del propio estadounidense (iniciada con el establecimiento de las colonias inglesas en el Siglo XVII). En cuanto a ello, es de recordar que los puritanos arribaron a lo que hoy se conoce como EE.UU. en el Mayflower en 1620, siendo en dicho siglo que el asentamiento de estas personas 
abrió paso a la fundación de las trece colonias, que gozaban de cierta autonomía brindada por Inglaterra, motivo por el que los colonos pudieron experimentar formas de autogobierno, surgiendo con ello estados que tenían sus propias constituciones (López Monroy, 2003). Y un siglo después se integrarían bajo una unión con la adopción de la Constitución de los EE.UU. de 1787.

En cambio, el federalismo mexicano es distinto, puesto que se compone de una dualidad política vinculada a un centralismo, pero contraría las intenciones del Congreso Constituyente de 1916-1917, que concibió al federalismo en tres esferas constitucionales, siendo primera en tiempo la esfera municipal y el gobierno que la rige. Para entender la anterior afirmación, se deben tener en cuenta las diferencias entre municipio (territorio) y ayuntamiento (gobierno) dado que, antes de la llegada de los españoles, ya existía una organización territorial similar al municipio concebido en Europa. Aquí es muy importante detenerse a reflexionar que el vocablo "municipio" deviene del latín que, como es sabido, fue un idioma que se originó en Europa desde la Antigüedad. No obstante, que del latín se originara la palabra "municipio" no quiere decir que en otros colectivos coetáneos a la época fuera de Europa no se compartiera una noción igual a esta, pero claramente en una lengua distinta.

En este orden de ideas, en el México prehispánico, de acuerdo con Sotelo Inclán (1943), existía el calpulli o chinancalli, que ya en nuestras palabras era el equivalente de lo que se conoce como municipio agrario. Según dicho autor, esta institución se fue consolidando de una generación a otra a pesar de que su denominación cambiara con la influencia de los españoles, quienes no los desaparecieron, sino que respetaron su estructura de producción agraria. Así, sus cabecillas o calpuleques eran ayudados por jueces, alcaldes, regidores y otros ministros de justicia todos ellos nombrados por elección popular. En efecto, es llamativo el hecho de que la forma de organización territorial de los naturales (municipio agrario) fuera respetada, lo que se debió a esa visión jurídica que la Corona española tenía en relación a las Indias Occidentales. Levene (1973)

\section{DERECHO GLOBAL. ESTUDIOS SOBRE DERECHO Y JUSTICIA}


explica que las Indias no eran colonias ni factorías, sino provincias, reinos, señoríos y repúblicas, fueron incorporadas a la Corona de Castilla y León, sin poder ser enajenadas. Menciona que sus naturales eran iguales en derecho a los españoles europeos, consagrándose la legitimidad de los matrimonios y existía la sujeción a un solo Derecho, pues, para aquello que no estuviera previsto en las Leyes de Indias, se estaría a lo dispuesto por las de Castilla siguiendo el orden de prelación de las Leyes de Toro (Levene, 1973).

Estos designios de la corona perduraron incluso hasta inicios del Siglo XIX, ya que la Constitución Gaditana estableció que la nación española se componía por la reunión de todos los españoles de ambos hemisferios, siendo españoles todos los hombres libres nacidos y avecinados en los dominios de las Españas y los hijos de estos. Como contrapartida, en los EE.UU. sí se establecieron colonias inglesas y los colonos no concebían el matrimonio entre europeos y los naturales de esas tierras. En cambio, el Derecho Indiano sí permitía este tipo de uniones, que se perpetuaron a través de la historia en ambos hemisferios. Para un mejor saber y entender, como constancia de esta consagración, aún se yerguen palacios reales que eran propiedad de descendientes de expedicionarios españoles y de la nobleza azteca, como en el caso de la ciudad de Cáceres, en la Comunidad Autónoma de Extremadura (tierra de conquistadores), en España, lugar donde se encuentra el Palacio de Toledo-Moctezuma, y además una estatua de considerables proporciones dedicada a Nezahualcóyotl

Las intenciones documentadas de la Corona eran dotar a esta organización territorial de los naturales con una nueva estructura de gobierno, sin desaparecerla. De hecho, en la Real Cédula de 1560 de Felipe II, se advertía a los pobladores que respetaran estas tierras (Sotelo Inclán, 1943), apostillando estas aspiraciones dicho monarca en sus Ordenanzas de descubrimiento, nueva población, y pacificación de 1573. De ellas se desprende que la Corona quería integrar estas tierras al reino para que se beneficiaran en aspectos tales como la planeación urbana, la producción agraria, la posesión de bienes, oficios y para la supuesta 
salvación que ofrecía la religión católica, incluso para la convivencia fraternal entre naturales y los pobladores europeos (Fernández Sotelo, 1987). Ahora bien, se debe aclarar que algo distinto a los designios de la Corona fue lo ocurrido ya en el nuevo territorio, lo que orilló a muchos indígenas a abandonar sus tierras. Empero, aún con ello, la Corona continuaba, al menos de manera oficial, enfatizando el no despojar de sus tierras a los naturales, tal como se demuestra en los Mandamientos Virreinales de 1603 y 1606 de la Nueva España (Sotelo Inclán, 1943). Huelga mencionar que los abusos cometidos en contra de los naturales orillaron a juristas y teólogos españoles como Vitoria y De las Casas a defender los derechos de estas personas, sentando las bases doctrinales para el reconocimiento de la libertad y dignidad de todos los seres humanos (Pérez Luño, 2013).

La situación relativa al territorio de los naturales empeoró con la Independencia de México, ya que jurídicamente se cometieron abusos, específicamente con el acaparamiento de tierras a partir de 1824. En otras palabras, aquello que la Corona prohibió en relación al sistema de producción de los naturales y la no enajenación de sus bienes, la naciente nación mexicana no lo respetó. Esto originó el descontentó en los habitantes que precisamente comenzaron a recurrir a los citados documentos emitidos por la Corona para argumentar que por derecho les correspondían esas tierras. Ejemplo de ello es el escrito presentado en 1853 ante el Archivo General y Público de la Nación por los vecinos del Pueblo de San Miguel Anenecuilco, Morelos (que antiguamente fue un calpulli), a efecto de rescatar la aludida Cédula Real y los Mandamientos virreinales. Años más tarde en ese mismo lugar, nacería de una genealogía de calpuleques (por la consagración del matrimonio entre naturales y españoles), Emiliano Zapata (Sotelo Inclán, 1943), quien tomó originalmente la bandera de la devolución de tierras durante la Revolución Mexicana de inicios del Siglo XX. Ello sumado a otros factores trajo como resultado la adopción de una nueva constitución en 1917 que consignó la libertad municipal, pero que aún contiene graves omisiones, como se abordará en el siguiente apartado.

\section{DERECHO GLOBAL. ESTUDIOS SOBRE DERECHO Y JUSTICIA}


Ya por lo que respecta a la estructura de gobierno municipal, es decir, el ayuntamiento, sus primeros antecedentes en México se remontan a 1519, con la fundación de la Villa Rica de la Vera Cruz. Siendo esta la primera vez que se usó en el México prehispánico la denominación de municipio (su esencia ya existía en forma de calpulli). De la lectura de Díaz del Castillo (1986), Madariaga (1970) y Duverger (2019), es posible argüir que la creación de ese municipio español no correspondía al simple placer personal por fundar de los conquistadores liderados por Hernán Cortes, sino más bien fue la excusa perfecta para establecer las condiciones jurídicas de la legitimación de la conquista, pues los ahora pobladores de esa nueva ciudad, eran ya ciudadanos de la Villa Rica de la Vera Cruz. Como se desprende de Duverger (2019), Cortés era consciente de cuál era la esencia del poder de una ciudad (el cabildo). Además, siguiendo a este autor, sabía que en la carrera por el poder el sufragio popular representa un arma comparable a la gracia de un monarca, a tal grado que hizo constar en papel los resultados de las elecciones del cabildo de dicha ciudad, que integró a las nuevas autoridades, quienes a su vez lo nombrarían capitán general y oficial de justicia (justicia mayor), sustentando de esta forma en el Derecho su designación. Por ende, esto comprueba, dentro de los antecedentes del sistema político mexicano, cómo el pueblo ha ejercido su soberanía a través de los poderes de la esfera municipal.

En síntesis, la organización territorial de los municipios en México corresponde a una simbiosis histórica entre los calpullis (municipio agrario) y el municipio español; mientras que el antecedente inmediato del primer ayuntamiento en México se tuvo en 1519. Este último, como se ha enfatizado, es la estructura de gobierno que rige al territorio conocido como municipio, en ese momento histórico, a la Villa Rica de la Vera Cruz. Dentro de esa estructura de gobierno municipal, el cabildo fue el constituyente de un orden jurídico que depositó en la persona de Cortés las figuras de capitán general y justicia mayor, permitiéndole así ser el caudillo para la guerra, teniendo el mando de la fuerza pública, y además fungir como el administrador de justicia en nombre del rey (López de Gómara, 
1552, ed. 2000; Madariaga, 1970). Siendo esta la primera esfera de gobierno, antes que los estados y la federación.

Por su parte, la segunda y tercera esfera del federalismo en México (es decir, los estados y la federación como la unión política de los primeros) fueron concebidas jurídicamente hasta después de la Independencia en el Siglo XIX. En cuanto a ello, es de recordar que el proceso de federalización en México fue centrífugo (de adentro hacia afuera), a diferencia del estadounidense que inicialmente fue centrípeto (de afuera hacia dentro). Es decir, en la costa este de lo que hoy son los EE.UU. prexistían estados independientes que decidieron pactar para conformarse en una federación, pero en México, hubo una diseminación desde el centro político sin que existiesen estados previamente constituidos (Sánchez de la Barquera y Arroyo, 2014). Muchos de los estados no existían en ese momento. Este fue el caso, por mencionar un ejemplo, de Tabasco, reconocido propiamente como estado con la Constitución de 1824, puesto que antes de ella era parte de la Intendencia de Yucatán (Barceló y Piña, 2010). Se comprende que la creación del estado de Tabasco no fue antes ni inmediatamente después de la consumación de la Independencia en 1821. La semilla de su independencia como estado, en realidad, fue gracias al Ayuntamiento de Villahermosa, puesto que este nombró a Eduardo Cárdenas para que abogara por la autonomía de Tabasco ante las Cortes de Cádiz en 1812 (Gurria Lacroix, 1979). Ua evidencia histórica más de cómo a través de la esfera municipal el pueblo ejerce su soberanía y que incluso fue la impulsora de la consolidación de la segunda esfera del federalismo en México. De esta manera, el proceso de federalización en México, en cuanto a la creación de estados, terminaría incluso en las postrimerías del Siglo XX.

A ello se agrega el hecho de que en este proceso de federalización en México no se respetaron las estructuras de organización territorial del capulli y sus sistemas de producción, por lo que el municipio y su gobierno fue relegado jurídicamente en las constituciones federales. Se ha ignorado que el poder de un ayuntamiento en el sistema político mexicano (como estructura de gobierno del municipio)

\section{DERECHO GLOBAL. ESTUDIOS SOBRE DERECHO Y JUSTICIA}


es previo al poder de otras esferas que fueron previstas con posterioridad a la independencia de nuestro país (estados y federación). Rememoremos que las fuentes del Derecho, en orden cronológico, son materiales o reales (hechos sociales), históricas (documentos históricos) y formales (procesos de creación de normas), y todas ellas comprueban que la esfera municipal fue la primera, como se ha venido analizando y se seguirá argumentando a lo largo de este artículo.

\section{LA EXCLUSión CONSTITUCIONAL DEL AYUNTAMIENTO COMO PARTE “NO INTEgRANTE" DEL PACTO FEDERAL EN MÉxICO}

La esfera municipal ha sido de antaño excluida del pacto federal de iure y de facto a través de la historia, sobre todo a partir de 1824. La exclusión del ayuntamiento municipal fuera del pacto federal se puede estudiar en dos diferentes facetas, la primera es relativa a su consignación constitucional y la segunda a los actos de las otras esferas constitucionales en detrimento del mismo.

En cuanto a la primera faceta, si bien el ayuntamiento municipal representa la esfera primigenia del federalismo mexicano, no fue sino hasta inicios del Siglo $\mathrm{XX}$, como uno de los resultados de la Revolución Mexicana, que se sentaron las bases normativas de un "municipio libre". Resulta paradójico que, antes de dicho hito, los regímenes centralistas o unitarios de la Historia de México (como el virreinato y los gobiernos centralistas del Siglo XIX, incluyendo el Imperio de Maximiliano) le otorgaron mayores facultades y competencias al ayuntamiento, a diferencia de los regímenes liberales y federales también decimonónicos. Esto en razón de que los sistemas unitarios, no obstante ser centralistas en el ejercicio de los poderes del gobierno, parten de la esfera municipal, aunque esta última esté encuadrada dentro de una estructura jerárquica y escalonada en una clara dependencia respecto de los órganos nacionales, propiciando que en la esfera municipal se ejecute el orden jurídico nacional. También puede ser el caso que las provincias o departamentos tengan facultades sumamente amplias de cara a 
los municipios, algo que sucedió con ciertas constituciones locales en el siglo pasado en México, como la Constitución de Baja California de 1953, que en su artículo $5^{\circ}$ establecía la figura de "superior jerárquico", quien era el gobernador del estado, ocurriendo lo mismo con la Constitución de Michoacán (Del Rivero del Rivero, 1986). Hoy en día a pesar de que México cuenta con un sistema federal, la esfera municipal no se establece expresamente como integrante del pacto federal, solo los estados representan las entidades federativas. Otras veces se sobreentiende que la esfera municipal sí es parte, sobre todo, cuando se trata de establecer obligaciones fiscales y constitucionales, sin embargo, existe la confusión de jerarquizarla.

Ahora bien, se debe mencionar que una de las causas determinantes de la Revolución Mexicana fue precisamente el descontento de los pueblos y sus ayuntamientos en contra de la institución denominada jefatura política. Esta última desplazaba al gobierno de los municipios y fungían como instrumento de control del porfirismo. Aunado a ello, había un sometimiento a los gobernadores, las condiciones de esclavitud del campesinado y la explotación de obreros (Quintana Roldán, 2008). Por consiguiente, el reconocimiento constitucional en 1917 del municipio libre se debió a motivos históricos propios de nuestra nación, tal como sucedió con la adopción originaria del federalismo dentro del sistema político mexicano. De acuerdo con Rabasa (1997), este último hecho, además de suprimir el absolutismo, también hizo posible “...otorgar a las antiguas provincias de la Nueva España, cuya penuria había sido más por el abandono que por una dominación efectiva, los mismos principios de autosuficiencia política que se otorgaban al gobierno federal..." (p. 29). Recordando en este punto que la antigua provincia española era una división de índole administrativa, intermedia entre el Estado (entendido como nación) y el municipio (Cabanellas, 1989d), lo que hoy se conoce como estados en nuestro sistema, que antes no eran autosuficientes políticamente de acuerdo con Rabasa (1997). Panorama similar pesaba sobre el gobierno municipal en México, puesto que estaba subyugado a otras esferas como la jefatura política, los gobernadores y, desde luego, la federación. 
Fue por tales motivos que una de las banderas de la Revolución Mexicana fue el municipio libre. Al respecto, Venustiano Carranza, artífice del proyecto de la CPEUM, visionó al municipio independiente como una de las grandes conquistas de la revolución, ya que para él este era la base de un gobierno libre, especificando que dicha conquista daría libertad política a la vida municipal, así como independencia económica, para lo cual tendría fondos y recursos propios para la atención de sus necesidades. Entendía que era necesario para el municipio substraerse de la voracidad insaciable que hasta ese momento habían demostrado los gobernadores. En cuanto a ello, señaló la importancia de que existiese una ley electoral que los mantuviera completamente alejados del voto público y que castigase con severidad toda tentativa de violación (Citado en Del Rivero del Rivero, 1986 y 2017). Carranza no solamente hablaba de libertad para el municipio, sino también de autonomía e independencia para el mismo. Señalaba que este era la base de la libertad política de los pueblos, la primera condición de su bienestar y prosperidad, teniendo en cuenta que las autoridades municipales son las más indicadas para conocer, atender y remediar las necesidades del pueblo, en razón de su estrecha proximidad a este (Citado en Aguirre Berlanga, 1985). Así, como fruto de sus aspiraciones constitucionales, surgió el proyecto que reformaba la Constitución de 1857, para ser presentado ante el Congreso Constituyente de 1916-1917.

Lamentablemente, ya dentro del Congreso Constituyente hubo diputados que desvirtuaron estos ideales, porque al municipio solo se le dotó de libertad en la esfera administrativa, omitiendo su autonomía y mencionarlo, sobre todo, en el artículo 41 Constitucional. A pesar de ello, hubo otros diputados constituyentes que pugnaron por la soberanía que ejerce el pueblo a través de los poderes del municipio, como el caso de Pastrana Jaimes (1917), quien argumentó lo siguiente:

Primeramente, la soberanía se ejercita por la autoridad municipal; después, por las de los Estados, y en último lugar, por las autoridades de la República. 
$(\ldots)$

En los ayuntamientos encontramos los gérmenes de todos los poderes; el germen del Poder Judicial, el germen del Poder Ejecutivo y el germen del Poder Legislativo. El ayuntamiento es un Poder, se quiera o no se quiera. Que el ayuntamiento no pueda dictar leyes, es una mentira. (Pastrana Jaimes, 1917, citado en Comisión Nacional para la Celebración del Sesquicentenario de la Proclamación de la Independencia Nacional y del Cincuentenario de la Revolución Mexicana, 1960, pp. 164 y 165).

Cabe mencionar que Pastrana Jaimes incluso presentó durante los debates del Congreso Constituyente en 1917 una propuesta para que el artículo 41 incluyera que el pueblo ejerce su soberanía también por los poderes del municipio libre e independiente, pero infortunadamente no fue aprobada. En efecto, su propuesta se acercaba más a la visión del autor del proyecto constitucional: Carranza.

A las anteriores palabras, se aúnan los ideales del diputado constituyente Heriberto Jara (1917), presentes también en el mencionado Diario de Debates del Congreso Constituyente de 1916-1917, quien, partiendo de la necesidad imperiosa de incluir constitucionalmente al ayuntamiento municipal como parte del pacto federal, señala lo siguiente:

(...) el pacto federal lo entiendo a base de un respeto mutuo, a base de una verdadera concordia y no a base de invasión a la soberanía. Hemos venido luchando por conseguir la soberanía, arrancando desde los municipios; de allí es que con todo entusiasmo, más bien con ardor, hemos aceptado el proyecto del Primer Jefe en lo que atañe a este punto. ¿Por qué? Porque al Municipio lo consideramos como la base de nuestras instituciones, porque son los pequeños organismos que forman el gran conjunto; ojalá, señores, que a los municipios, que también en pequeño tienen sus tres poderes y también en pequeño tienen su 
Poder Legislativo en el Cabildo, su Poder Ejecutivo en el presidente municipal y el Poder Judicial en los jueces, se les tenga el mismo respeto que ahora se tributa a los Estados de la Federación. Entonces habremos conseguido nuestro ideal, entonces habremos establecido una verdadera libertad, una verdadera soberanía. (Jara, 1917, citado en Comisión Nacional para la Celebración del Sesquicentenario de la Proclamación de la Independencia Nacional y del Cincuentenario de la Revolución Mexicana, 1960, p. 809).

No obstante dichas intenciones expresadas durante los debates del constituyente, la CPEUM aprobada omitió incluir a la esfera municipal como parte integrante del pacto federal. Esto se refleja en diversos artículos constitucionales que van desde el 40 al 43. En concreto, el artículo 40 establece que es voluntad del pueblo mexicano constituirse en una república federal, "compuesta de Estados libres y soberanos (...) pero unidos en una federación”. El artículo 41 señala que el "pueblo ejerce su soberanía por medio de los Poderes de la Unión (...) y por los de los Estados y la Ciudad de México", sin mencionar a los municipios. Por su parte, el artículo 42 preceptúa que el territorio nacional comprende el de "las partes integrantes de la Federación”, aclarando subsecuentemente el artículo 43 que las partes integrantes de dicha federación son los estados y la Ciudad de México, enunciándolas pormenorizadamente y omitiendo a los municipios (Cámara de Diputados del H. Congreso de la Unión, 2020).

Así pues, en la doctrina académica también se encuentran reflexiones en torno a las fatídicas omisiones de estos artículos constitucionales relativos al pacto federal. Ortega (2001) subraya la necesidad de establecer que el pueblo ejerce su soberanía a través de los poderes municipales, y no solo de los estados o los de la unión. Incluso desde principios del Siglo XX se ha venido exponiendo esta situación. Este es el caso de Castorena (1926), quien evidenció que la CPEUM no reconoce expresamente en el artículo 41 que la esfera municipal cuente con "poder político", como sí lo hace respecto de los estados y la federación, aunque más adelante el autor concluye que del artículo 115 puede desprenderse que, en 
efecto, esta esfera cuenta con dicho poder político, en específico aludiendo a la expresión "organización política". Sin embargo, la propia historia revela que no ha sido suficiente, puesto que, como se reflexionará infra, tal falta de precisión normativa ha permitido a las autoridades interpretar la norma indistintamente.

En relación al tema de la soberanía municipal, Ruiz Massieu (1982) señala que el municipio no es soberano, tampoco cuenta con autonomía y no puede fijarse su competencia, ya que esta última es atribuida por un poder externo, ya sea por el poder constituyente nacional, por el estatal o bien por la legislación local. Por su parte, el análisis de Muñoz Ledo (2019; citado en Cámara de Diputados del H. Congreso de la Unión, 11, marzo 2020) resulta muy oportuno, puesto que dilucida que la omisión del artículo 41 representa un "error teórico y jurídico", en la inteligencia que la soberanía original reside en el municipio en razón de ser la primera expresión del voto popular, lo que justifica, en palabras del diputado federal, invertir la pirámide del federalismo. A ello agregaríamos la importancia de recordar que fue el ayuntamiento el que impetró por primera vez de forma jurídica la independencia de México en 1808. Continuando con dicho autor, agrega que, al igual que los estados cuentan con una Conferencia Nacional de Gobernadores (CONAGO), debe existir una institución similar para los municipios en aras de fortalecer la "asociatividad municipal", principio que está reconocido constitucionalmente, pero no se ha extendido. Esto debido a que las asociaciones o conferencias de municipios actuales, como la Conferencia Nacional de Alcaldes de México, no es un ente de carácter público que forme parte del Estado, sino que es un ente de derecho privado (Arredondo citado en Cámara de Diputados del H. Congreso de la Unión, 12, agosto 2019).

En síntesis, la CPEUM solo reconoce como partes integrantes de la federación a los estados, no bastando con lo consignado por el artículo 115 constitucional que establece que el municipio libre es la base de la división territorial y de la organización política y administrativa de los estados, lo que es diametralmente distinto a establecer expresamente que el pueblo ejerce su soberanía a través de los poderes municipales y que esta esfera es parte integrante del pacto federal. 
Asimismo, dicho artículo esclarece que los estados tendrán una forma de gobierno republicana, representativa, democrática, laica y popular, mas no federal. Esto se puede contrastar, como parte de un ejercicio de Derecho comparado, si bien no con la Constitución de los EE.UU. debido a que su composición constitucional federal es dualista, pero sí con la Constitución de Brasil, que señala en su artículo 1: "La República Federativa de Brasil, formada por la unión indisoluble de los estados y municipios y del Distrito Federal, se constituye en un Estado Democrático de Derecho...” y el artículo 18 "La organización políticoadministrativa de la República Federativa de Brasil comprende la Unión, los Estados, el Distrito Federal y los Municipios, todos autónomos en los términos de esta Constitución" (Traducción propia de Câmara dos Deputados do Brasil, 2020). A su vez, la Constitución de la Nación Argentina, en su artículo 123, establece que las provincias deberán asegurar la autonomía de los municipios (Congreso de la Nación Argentina, 1995).

Por lo observado, tanto Brasil como Argentina, ambos sistemas federales, de los pocos que hay en América Latina, reconocen constitucionalmente la autonomía municipal de manera expresa, consignación que no se vislumbra en la CPEUM, en el entendido que libertad y autonomía son conceptos distintos. La libertad es un aspecto subjetivo de la persona, no de las entidades políticas. La autonomía, en cambio, es relativa a la capacidad de un ente para adoptar sus propias normas. Esto conduce a cuestionarnos, ¿entonces libertad para qué tiene la esfera municipal? En realidad, cuando el Congreso Constituyente de 1916-1917 rechazó por mayoría de votos la propuesta de Pastrana Jaimes, se dejó claro que la libertad del municipio era solo en su faceta administrativa, no en lo político, pues en este último aspecto era necesario que existiese una mayor centralización. Además, se señaló que los municipios no pueden determinarse a sí mismos, que no pueden darse leyes $\mathrm{y}$, por ende, no fueron considerados como entidad política ni soberana (Medina, 1917 citado en Comisión Nacional para la Celebración del Sesquicentenario de la Proclamación de la Independencia Nacional y del Cincuentenario de la Revolución Mexicana, 1960). Como consecuencia, la normatividad constitucional en relación al municipio es omisiva del valor que 
esta esfera ha tenido a través de la historia de México y que sin duda debería ser tomada en cuenta dentro de la noción del pacto federal.

Ahora bien, en referencia a la segunda faceta de la exclusión de la esfera municipal, que está relacionada a los actos invasivos de otras esferas con motivo de las omisiones constitucionales, se tienen algunos ejemplos históricos de cómo se ha mermado su autonomía a través del tiempo. Es menester abordar la desaparición de las municipalidades en el entonces Distrito Federal, bajo la iniciativa del expresidente Álvaro Obregón a fin de reelegirse en el cargo, puesto que esta entidad había sido bastión del Partido Laboralista. Dicha reforma publicada en el Diario Oficial de la Federación el 20 de agosto de 1928, sancionada por el otrora presidente Plutarco Elías Calles, permitiría al titular del ejecutivo federal designar a las autoridades de la capital, por lo que el artículo 73, fracción VI, señalaba ahora en su primer punto que "El Gobierno del Distrito Federal estará a cargo del Presidente de la República, quien lo ejercerá por conducto del órgano u órganos que determine la Ley respectiva”; fracción que actualmente se encuentra derogada (Diario Oficial de la Federación, 20, agosto 1928; Zarauz López, 2016). Este acto sentó un precedente en la impronta política para que en un futuro inmediato otros titulares del poder ejecutivo federal o de los estados pudieran conducirse bajo los mismos términos en detrimento de la esfera municipal. En este sentido, la historia revela que para la federación o para una entidad federativa sí les es permisible desaparecer un municipio a pesar de que el ayuntamiento municipal representa la primera esfera del pacto federal. La idea del municipio como esfera integrante del pacto federal fue parte de los ideales del Congreso Constituyente de 1916-1917. Por ende, fue concebido por el constituyente como ente dotando de autonomía y libertad frente a las otras dos, pero unidas en un solo pacto. ¿Acaso sonaría lógico que un municipio pueda desaparecer a un estado o a la federación? Ciertamente no tiene facultades para ello, pero tampoco deberían corresponder a los poderes ejecutivos de otras esferas eliminar a un municipio que se encuentra legitimado por el pacto federal y que además es la base de la organización territorial y de la organización política y administrativa de los propios estados tal como lo señala el artículo 115 de la CPEUM. 
Aunado a ello, como sabemos un verdadero federalismo debe prever mecanismos de control para la defensa de las disposiciones constitucionales que fijan las competencias entre sus esferas. Por ejemplo, la Constitución de los EE.UU. establece en su artículo 3, sección II, la posibilidad de que el Poder Judicial entienda de todas aquellas controversias que se susciten entre los estados que integran dicha nación. De manera puntual, en México este mecanismo es denominado controversia constitucional, reconocida en el artículo 105, fracción I, de la CPEUM. Históricamente solo se le permitía promoverla a los estados y a la federación, no así al municipio, ya que el texto constitucional original de 1917 no le otorgaba esta facultad. En consecuencia, durante gran parte del Siglo XX prevalecieron criterios de la Suprema Corte de Justicia de la Nación (SCJN), que establecían que el municipio no podía hacer valer sus derechos ante controversias constitucionales con un estado o la federación por no considerar que poseía "poder político". Resulta ejemplificativa una jurisprudencia del Pleno de la SCJN de la Quinta Época, relativa a la personalidad de los municipios, en la que determinaba que, a pesar de que la base de la división territorial y de la organización política y administrativa de los estados es el municipio libre, y no obstante este sea independiente del Poder Ejecutivo y Legislativo, los municipios no tenían poder político para efectos de que la SCJN conociera de las controversias que se suscitaran entre los ayuntamientos y los poderes de un mismo estado. Lo anterior bajo la argumentación que los ayuntamientos carecían de jurisdicción sobre todo el territorio del estado (Pleno SCJN, 1935). Ante la omisión constitucional y los criterios judiciales en su contra, las esferas municipales hacían valer su competencia a través del juicio de amparo legitimando su acción al ser una persona moral para los efectos del mismo (Ferrer Silva, 2007). Es de mencionar que, en sistemas jurídicos previos al iniciado a partir de 1917, las controversias de este carácter podían ser resueltas ante los senados locales, pero estos dejaron de existir con el paso del tiempo.

Empero, a principios de la década de los noventa, la SCJN resolvió el célebre amparo 4521/90, denominado "amparo Mexicali", aduciendo que el municipio 
representa un poder puesto que ejerce las funciones ejecutivas, legislativas y judiciales, propias de un poder político, derivando esto en una reforma constitucional en materia de control de constitucionalidad, en donde ya se reconocía el derecho a promover controversias constitucionales a los municipios (Valencia Carmona, 2012). Es decir, más de cincuenta años después a la adopción de la constitución de 1917, cuya intención desde su origen era precisamente esa como revelan los debates de su Congreso Constituyente.

En adición a ello, la esfera municipal, al tener propiamente poder político, al igual que los estados y la federación, debería contar con las tres funciones en que se divide este para su ejercicio (legislativo, ejecutivo y judicial). Dicha aseveración se encuentra aparejada a las palabras previamente referenciadas por Heriberto Jara, asentadas en el Diario de Debates del Congreso Constituyente de 1916-1917, quien señala que el poder legislativo reside en el cabildo; el ejecutivo, en el presidente municipal; y el judicial, en los jueces municipales. Todos ellos conforman la noción de ayuntamiento entendida como gobierno municipal, que no es sinónimo del poder ejecutivo municipal. De esto surge la interrogante relativa a si haría falta establecer constitucionalmente que también los municipios cuenten con una división de funciones, al igual que los estados y la federación. Esto no es un hecho aislado para el Derecho comparado, ya que otros países federales representan un paradigma al respecto. Por ejemplo, la Constitución de Brasil establece en su artículo 31 las expresiones portuguesas "Poder Legislativo Municipal" y "Poder Executivo Municipal", además de que también prevé tribunales de cuentas en la esfera municipal a lo largo de su texto (Câmara dos Deputados do Brasil, 2020). En el caso del sistema federal argentino, su constitución nacional no hace referencia a una división de poderes en la esfera municipal, pero sí se les reconoce expresamente su autonomía. Y precisamente en ejercicio de esta autonomía, se puede mencionar el ejemplo de la Carta Orgánica Municipal de la Ciudad de Córdoba de la que se desprende una separación de funciones entre el Concejo Deliberante (legislativo), el Departamento Ejecutivo y la existencia de jueces y tribunales relativos a la 
justicia municipal de cuentas, de faltas, fiscal, administrativa e incluso electoral. Y no solo esto, sino que además existen pesos y contrapesos entre el legislativo y ejecutivo municipales. Por ejemplo, en el artículo 74 de dicha Carta se prevé que el Ejecutivo, que no es parte del Concejo Deliberante, puede ejercer el veto en contra de las ordenanzas aprobadas por el segundo volviendo el proyecto a este. Sin embargo, en caso de que lo apruebe una mayoría de dos tercios del Concejo el proyecto se considerará ordenanza, pasando al Ejecutivo para su publicación y promulgación a menos que este haga uso de su facultad para someterla a referéndum. Aunándose a esto, en el artículo 113 se encuentra la facultad que tiene el Concejo Deliberante para denunciar al Intendente, Vice-intendente (ambos son parte del ejecutivo municipal), concejales (legislativo) y miembros del Tribunal de Cuentas municipal por mal desempeño en sus funciones o por incapacidad o incompatibilidad (Convención Municipal Constituyente, 1995).

Otro ejemplo en el sistema federal argentino es la Constitución de la Provincia de Buenos Aires, que en su artículo 196, prescribe que los conflictos internos de los municipios, ya sean producidos entre los departamentos ejecutivo y deliberativo, o bien que ocurran dentro del último, serán dirimidos por la Suprema Corte de Justicia de Argentina (Convención Constituyente de la Provincia de Buenos Aires, 1994). Cabe señalar que en México la CPEUM no consigna esta posibilidad para la esfera municipal, sobre todo porque no están divididas sus funciones.

Siguiendo esta tesitura, es inexorable que los gobiernos municipales, en su calidad de entidades federativas dotadas de poder político, se guíen y actúen bajo el principio de división de poderes. Resulta ser un vasallaje petrificado para la historia del constitucionalismo que aún hoy en día la CPEUM sea omisa en evitar normativamente que los ayuntamientos en México entremezclen funciones ejecutivas y legislativas, e incluso es inconcebible que se prescinda del poder judicial municipal que históricamente ha formado parte del sistema político mexicano. Esto se debe principalmente a la inadecuada comprensión sobre el significado de un ayuntamiento, propiciando que existan serias deficiencias en el ejercicio de su poder político. Comenzando con la función legislativa, puesto que 
las disposiciones que aprueba el cabildo, sean los denominados bandos de policía y gobierno, o sus correspondientes reglamentos, usualmente son cambiados cuando hay alternancia en el titular de la función ejecutiva, que es el presidente municipal. Sería importante que tanto la CPEUM y las constituciones locales de los estados definan de manera adecuada que los ayuntamientos dividirán sus funciones para gobernar, reforzando en primer lugar al órgano depositario de la función legislativa municipal, que es el cabildo integrado por personas elegidas mediante sufragio, para que de forma efectiva ejerza los frenos y contrapesos respecto de la función ejecutiva. Esto evitaría que se cambie de fondo la normatividad sustancial del municipio cada tres años, situación que termina generando un alto costo para el colectivo dado que hay proyectos institucionales u obras de mantenimiento a los que no se les da seguimiento con el cambio de administraciones. En efecto, sería oportuno que el ejecutivo municipal proponga modificaciones y, en su caso, sean aprobadas en sesiones de cabildo, pero se considera totalmente inaceptable un cambio radical de normatividad cada trienio. Es imprescindible para la ciudadanía contar con mayor certeza jurídica respecto de la institución que representa la primera expresión de la soberanía en México, evitando a su vez menos erogaciones con cambios de proyectos y obras, en lugar de darles continuidad, lo que ha lacerado la memoria histórica del pueblo con el excesivo rediseño de ciudades. Empero, este análisis no propone instituir necesariamente un órgano constituyente municipal a efecto de adoptar un documento fundamental rígido, a modo de constituciones municipales, como el caso de las Cartas Orgánicas Municipales en otros sistemas políticos como el de Argentina (Mensa, 2007). O el ejemplo de las leyes orgánicas que rigen a los municipios brasileños y que son aprobadas y promulgadas por sus propias Cámaras Municipales, tal como se desprende del artículo 29 constitucional (Câmara dos Deputados do Brasil, 2020). Más bien, se considera menester fortalecer y reivindicar las funciones que históricamente ha tenido el cabildo como depositario de la función legislativa de la esfera municipal en nuestro sistema. Este aspecto también es permisible de ser estudiado a la luz de la división de poderes, en relación a lo cual memorables son las palabras del ilustre 
Locke (Citado en Tena Ramírez, 1948, p. 156) que menciona: "para la fragilidad humana la tentación de abusar del poder sería muy grande si las mismas personas que tienen el poder de hacer las leyes tuvieran también el poder de ejecutarlas".

Otro punto que debe destacarse sobre la esfera municipal en su función legislativa es que, si bien las legislaturas locales toman en cuenta a los cabildos de los ayuntamientos a efecto de aprobar una reforma a las respectivas constituciones de los estados, la CPEUM en su artículo 135 no establece que los congresos locales deban consultar a los cabildos municipales en aras de reformar la misma. De tal forma que surge la interrogante sobre por qué no se reivindica también el poder político de los municipios en el ámbito federal en relación a su función legislativa y el proceso de reformas a la CPEUM, ya que el orden constitucional local de cada estado no es el mismo que el orden constitucional federal. Al ser tres las esferas integrantes de esta unión política deberían todas participar en el proceso de reformas al texto fundamental que las rige. ¿Por qué las constituciones de los estados sí prevén consultar a los cabildos municipales para poder ser reformadas? ¿Por qué no hacer parte a la esfera municipal del proceso de reformas al texto fundamental federal, considerando que la base del sistema político mexicano es el municipio libre?

Ahora bien, no solo el poder legislativo municipal presenta deficiencias, sino también el poder ejecutivo, ya que la administración municipal enfrenta dos situaciones adversas, la primera en contra de la propia ciudadanía debido a que para acceder a ella no existe un mecanismo institucionalizado que permita seleccionar a las personas que cuentan con las aptitudes y el conocimiento que requiere la naturaleza de las funciones que desempeñarán en la esfera municipal (por ejemplo, en materia de servicios públicos), contexto que ocasiona eventualmente repercusiones en el disfrute de los mismos por parte de la población. Y la segunda en detrimento de los propios servidores públicos municipales, quienes no gozan de la estabilidad laboral dado que esta depende de los designios de nuevas administraciones, de modo tal que se ven impedidos para generar la 
experiencia necesaria en el servicio proporcionado a la población, provocando la ingobernabilidad de los servicios. Estas vicisitudes serían solucionadas con la creación de un servicio civil y profesional de carrera en la administración pública municipal en aras de hacer posible el manejo eficaz y honesto de los recursos del municipio (Del Rivero del Rivero, 1986).

Por otro lado, relacionado al poder judicial de esta esfera constitucional, resulta lamentable que la esencia original del juez municipal se encuentre extinta, salvo algunas excepciones como en municipios del Estado de Jalisco que conservan esa denominación, aunque su propósito no es lo que se conoce como la justicia de paz. Esta última es relativa a la administración de justicia en el grado inferior, tales como en los juicios verbales y de actos de conciliación, por lo que en razón de sus trámites, rapidez y falta de formalidades, aunado a la exigua cantidad de asuntos que en ella se litigan se distingue de la justicia común (Luna Arroyo y Alcerraga, 1982), figura que hoy en día se encuentra inserta en el poder judicial de los estados, y además se ha sustituido con los medios alternos de solución de conflictos, mientras que al municipio solo le corresponde la figura del juez calificador que está abocado principalmente a imponer infracciones de carácter administrativo por incumplimiento a los bandos de policía y gobierno, pero no se dedica a la justicia de paz. Los orígenes de los jueces municipales se remontan a la figura de "alcaldes" — de la voz árabe al'kade, que quiere decir "juez"-, quienes se dedicaban a impartir la justicia menor (Quintana, 2008), institución que fue importada a México por los españoles. En este sentido, Ortega (2001) expone que es menester “....establecer órganos jurisdiccionales municipales, a los que correspondería dirimir las controversias que se susciten entre la administración pública municipal y los particulares; así como impartir la justicia de paz" (p. 196). En casos concretos de algunas entidades federativas, como Tabasco, la justicia municipal dentro de la noción de ayuntamiento se remonta a 1825 , con la existencia de alcaldes que se dedicaban a la resolución de asuntos de menor cuantía, castigos correctivos, causas criminales leves y conciliaciones, en lo sucesivo, su denominación evolucionó a través del tiempo, hasta que en 1948 se

\section{DERECHO GLOBAL. ESTUDIOS SOBRE DERECHO Y JUSTICIA}


les denominó "jueces municipales", en virtud del Decreto No. 56 del entonces gobernador Francisco J. Santamaría, pero esta figura desapareció en la década de los setenta (Del Rivero del Rivero, octubre 2019).

Aparejado a lo anterior, otra institución que desapareció en detrimento de la completa incorporación de los municipios al pacto federal fueron los senadores locales, al respecto González Oropeza (citado en Ayllón González, 2010) señala que hubo estados que contemplaron la institución de un senado local entre 1824 y 1876, a estos correspondían distintas funciones, no precisamente como una cámara colegisladora, sino de control político de la constitucionalidad, solución de conflictos políticos, la ratificación de nombramientos, la supervisión de la administración pública y la representatividad de las regiones. Este último aspecto es sumamente importante para el núcleo de este artículo, ya que es una función que vindicaba la importancia de los municipios dentro del pacto federal.

Todo ello coloca al entramado constitucional y la actuación institucional de los entes que integran el sistema político mexicano, en una situación llena de carencias y abusos en lo relativo a uno de los cimientos del federalismo: el municipio. Un verdadero federalismo respetaría las esferas de cada una de las partes integrantes de tan aludido pacto, y uno de los aspectos neurálgicos de esas esferas es el gobierno que los rige, aquel conjunto de personas que ejerce el poder, pero la historia es el mejor testigo de las penurias y servilismo por los que ha atravesado el municipio como consecuencia de la no división de poderes.

\section{Conclusiones}

La historia revela que el gobierno Municipal, depositado en el Ayuntamiento, se estableció primero en tiempo, antes de las otras dos esferas constitucionales del Federalismo mexicano. Empero, dentro de este sistema político, se encuentra arraigada la idea errónea de que la forma de Estado Federal de nuestro país obedece a una jerarquización de "órdenes de gobierno" o "niveles", cuya cúspide la ocupa la 
Federación, seguida de los Estados, y, en último puesto, el Municipio. Al respecto, es importante, en primer lugar, comprender que el pacto federal en México es la unión de tres esferas Constitucionales, mas no de "órdenes de gobierno" dado que ninguno está por encima o debajo del otro, sino que las tres son autónomas y, lo que es fundamental aclarar, que el pueblo ejerce su soberanía a través de todas ellas. Razón por la que no resulta congruente que la CPEUM reconozca en su artículo 41 que el pueblo solo ejerce la soberanía a través de los poderes de la federación y de los estados, y no de la esfera municipal, con excepciones en algunos artículos constitucionales de los que se desprende que hay obligaciones para las tres esferas. En realidad, si se tomara estrictamente la concepción de soberanía de Jean Bodin, esta no podría dividirse ni cederse, entonces luego los estados no deberían ser considerados soberanos, sino autónomos.

Por otro lado, si se recurriese a la concepción jerarquizadora del federalismo, sería menester ubicar al ayuntamiento municipal como la primera esfera constitucional originada en los albores del Siglo XVI, seguida de la segunda y tercera esfera, estados y federación, respectivamente, que se consolidaron de forma jurídica hasta principios del Siglo XIX en México. Por ello, si bien es cierto que la soberanía reside esencial y originalmente en el pueblo, como lo establece la CPEUM en su artículo 39, el pueblo antes de constituirse en un estado o en una federación, primero se constituyó en un municipio, y para gobernarse instituyó la figura del ayuntamiento en el que se celebró la primera elección por sufragio, además esta primera esfera invocó la independencia de México y en algunos casos abogó por la creación de ciertos estados. A pesar de ello, la historia constitucional omite comentar al respecto.

A lo anterior, se aúna la confusión relativa a que el gobierno municipal es un sinónimo del poder ejecutivo depositado en la figura del primer edil conocido como presidente municipal. En cuanto a ello, se debe entender que el gobierno del municipio se ejerce por conducto del ayuntamiento, y no debe confundirse con la noción de municipio, que es el territorio en donde se ejerce dicho gobierno. En 
tal orden de ideas, a lo largo de este artículo se desprende que el ayuntamiento en su génesis etimológica corresponde a la acción y efecto de unirse, juntarse, o más propiamente, ayuntar personas para llevar a cabo determinado fin, en este caso, gobernar un territorio llamado municipio, lo cual prueba que teóricamente la palabra ayuntamiento también podría utilizarse en otras esferas, no solo la municipal o local. Así pues, el ayuntamiento, como figura constitucional depositaria del gobierno municipal, es un todo que no solo se reduce a la función ejecutiva. En realidad, la definición de gobierno es comprendida como el conjunto de personas que ejercen el poder político en un territorio dado, siendo este poder que para su ejercicio se divide en las funciones legislativa, ejecutiva y judicial. Por tal motivo, cada esfera constitucional en México tiene una división de poderes, tanto la federación como los estados, no así el municipio, contraviniendo los principios del Congreso Constituyente de 1916-1917, como se abordó en esta investigación.

Que la CPEUM no establezca que el ayuntamiento, en el ejercicio del poder que le es conferido, deberá dividir sus funciones, resulta ser una omisión grave que merma los cimientos de la primera esfera constitucional del federalismo, distorsionando la historia, puesto que de antaño la humanidad ha luchado porque los gobiernos tengan frenos y contrapesos, lo cual solo es posible dividiendo para su ejercicio los poderes del mismo. La división de poderes, en palabras de Tena Ramírez (1948): "no es meramente un principio doctrinario, logrado de una sola vez y perpetuado inmóvil; sino una institución política proyectada en la historia. De allí que sea preciso asistir a su alumbramiento y seguir su evolución..." (p. 155). Es de recordar la necesidad, evocando a Montesquieu, que el "abuso del poder solo se ve impedido si por la disposición de las cosas, el poder detiene al poder" (Citado en Villanueva Gómez, 2014, p. 154). La división de poderes en la esfera municipal también encuentra referencias en el Derecho comparado, ya que hay sistemas federales, como se discutió en este artículo en alusión a Brasil y Argentina, que reconocen normativamente la separación de poderes en los municipios, y que incluso establece mecanismos de control para evitar la invasión de competencias dentro de esta esfera. 
De esta manera, el no dividir propiamente las funciones del poder del ayuntamiento municipal ha conllevado a que existan aún serias ineficiencias en el federalismo mexicano y, por consiguiente, en la administración y conducción de los ayuntamientos, trayendo como consecuencia que el pueblo al que hace alusión la CPEUM, no pueda ejercer su soberanía a través del gobierno municipal. Ejemplo de ello es que los poderes del ayuntamiento se encuentran estancados en un escenario de vasallaje petrificado comparado al tiempo en el que se vive. Empezando con que el órgano legislativo municipal que debería fungir como peso y contrapeso ante la voluntad del primer edil para cambiar la normativa municipal fundamental, evitando así que se realice una abrogación a los bandos con cada alternancia de titulares del ejecutivo, es decir, cada tres años. Situación que es ignorada constitucionalmente, a tal grado que la ciudadanía de dicha jurisdicción se ve afectada por el vaivén de proyectos y obras inacabadas, y otras sin mantenimiento, debido a los cambios de administración, máxime cuando hay también una alternancia en los partidos políticos. A ello debe aunarse que, no obstante que los congresos de los estados tomen en cuenta a los cabildos municipales a fin de aprobar una reforma a sus respectivas constituciones locales, la CPEUM en su artículo 135 omite hacer parte expresamente del proceso de aprobación de reformas de su texto fundamental a la esfera municipal, pues solo consigna que se requiere la aprobación de la mayoría de las legislaturas locales, sin mencionar a los cabildos municipales.

Lo anterior también conduce a plantearse que los funcionarios municipales, sobre todo en la función administrativa, precisan de estabilidad laboral en sus respectivos cargos y funciones, ya que no resulta admisible el hecho de que estos sean transferidos de un puesto a otro dentro de la administración municipal debido al arribo de una nueva presidencia municipal, sin respetar la naturaleza de las funciones en las que ellos apenas cimentaban su experiencia. En el mismo sentido, es inaceptable que los cargos de la administración pública municipal sean asignados en virtud de recomendaciones, ignorando si existe o no la aptitud cognitiva y empírica por parte de esas personas para realizar las funciones que le 
correspondan. Por tal razón, es sumamente importante fortalecer al poder ejecutivo municipal en México, lo cual puede materializarse a través de la implementación del servicio profesional de carrera en la administración pública del municipio, pero no motu proprio, sino que sea parte de las obligaciones constitucionales de las autoridades. Por lo que respecta al poder legislativo municipal, función que recae, por supuesto, en el cabildo, no es permisible que exista un servicio profesional de carrera, ya que la ocupación de cargos en este ámbito de poder es guiado bajo el umbral de los principios democráticos. Ahora bien, dicho servicio también debería implementarse para el poder judicial municipal, sin embargo, primero es menester que exista este poder en la esfera municipal, lo que conduce al siguiente punto.

Es importante aclarar que se sustituyó la justicia de paz municipal por la de los jueces calificadores, que no son conciliadores ni tampoco conocen de asuntos de menor cuantía, sino que son sancionadores de infracciones administrativas a los bandos de policía y gobierno, depositando ahora la aludida justicia de paz en los poderes judiciales de los estados e implementado también los medios alternos de solución de conflictos (MASC). Esto encarece y burocratiza la justicia en nuestro país, a diferencia del juez municipal, pues con esta figura la justicia era pronta y expedita. Antes se tenía la figura de jueces municipales o alcaldes en el sentido propio de la palabra (que precisamente significa juez en árabe), quienes impartían la justicia de paz. Incluso es permisible mencionar que podían conocer de delitos no graves para ayudar a las partes involucradas a llegar a un acuerdo antes de ocasionar un daño aún más grave, función que, en contra de la soberanía municipal, hoy se ha conferido a los MASC que, desde una óptica personal y el conocimiento en la materia, erróneamente son considerados un derecho humano, que en su lugar es solo un procedimiento del debido proceso.

Otra figura que fue suprimida de nuestro sistema político es la de los senadores locales que fortalecían la representatividad de las regiones ante la esfera estatal, tal como hoy existe la Cámara de Senadores a nivel federal, pero que no era 
necesariamente una cámara colegisladora, era una institución que apuntalaba la soberanía de la esfera municipal como parte integrante de un pacto federal como estaba considerado en un principio.

Sería oportuno que la CPEUM fuera reformada en los artículos 40, el primer párrafo del 41, así como el 43. A efecto de que, respectivamente, se establezca en primer lugar que es voluntad del pueblo mexicano constituirse en una república compuesta de Estados y Municipios autónomos. En segundo lugar, que el pueblo ejerce su soberanía por medio de los Poderes de la Unión, por los de los Estados y por los de los Municipios. En tercer lugar, aclarar que también son partes integrantes de la federación los municipios. Esto en razón de que la CPEUM cuando se trata de establecer obligaciones sí toma en cuenta que son tres esferas las integrantes del pacto federal, como se puede apreciar, por mencionar un ejemplo, en el artículo $3^{\circ}$. Asimismo, sería conveniente que se reformara el artículo 115, en su fracción I, a fin de que establezca que el gobierno municipal que recae en el ayuntamiento dividirá sus funciones, al igual que los estados y la federación, respetando los principios del Congreso Constituyente de 1916-1917. A su vez, resulta importante que se fortalezca la fracción II de dicho artículo a fin de impedir que la normatividad fundamental del municipio sea cambiada cada tres años, sino solamente cada diez años en aras de evitar erogaciones innecesarias a la población, de forma tal que se establezcan políticas públicas sólidas y duraderas. También cabría la posibilidad de que en el propio artículo 115 se realizara una adición para implementar obligatoriamente el servicio civil y profesional de carrera municipal (Del Rivero Del Rivero, 1986). En adición, el artículo 135 constitucional debería consignar que para efectos de aprobar una reforma a la CPEUM se requiere además de la aprobación de las dos terceras partes de los individuos presentes en el Congreso de la Unión, la aprobación de la mayoría de las legislaturas locales, las que a su vez consultarán los respectivos cabildos municipales. 
Por último, es momento de replantearse la efectividad constitucional que sienta las bases estructurales de nuestra forma de Estado: el federalismo. Es inadmisible que la primera esfera del mismo sea eclipsada frente a los estados y la federación, es el ayuntamiento el que ha permitido al pueblo ejercer su soberanía a través de la historia de México, desde la legitimación de la conquista en el Siglo XVI, hasta la primera expresión de soberanía de los criollos de la Nueva España frente a la corona española en el Siglo XIX, siguiendo con la reivindicación del poder político de los gobiernos municipales de cara a los jefes políticos, gobernadores y federación que originó, aunado a la devolución de tierras, el proceso revolucionario del Siglo XX. Aún con ello, la CPEUM omite hacer parte al municipio del pacto federal, ocasionando que el gobierno municipal se encuentre actualmente en un escenario anacrónico y primitivo a la evolución del constitucionalismo, principalmente en alusión a la división de poderes. Así pues, el sistema político mexicano demuestra ser un sistema cósmico, ya que al igual que el cosmos, está lleno de claros-oscuros e indefiniciones, unas veces unitario (centralista) y otras veces federalista, pesando este vaivén político históricamente sobre la esfera municipal, que se encuentra cautiva de las omisiones constitucionales, ocasionando menoscabos a la primera expresión de soberanía del pueblo. Recordemos lo que nos enseña Levene (1973) que "sin Historia del Derecho, no hay Historia de la Civilización" (p. 8). Y dentro de nuestra historia, rescatamos las palabras de Blas Urrea (1909, citado en Instituto Nacional de Estudios Históricos de la Revolución Mexicana, 1985, p. 397), cuando dijo que "Nuestros municipios tienen ahora un campo de acción limitadísimo, y su obra es casi estéril, pues están ahogados por la autoridad de los jefes políticos, a quienes se han dado funciones incompatibles con el libre vuelo de la libertad municipal". Palabras que continúan vigentes. Por ende, no ayudemos a hacer de la historia una memoria inmoral, y con ello me refiero a rescatar de la egestad en la que se encuentra el municipio libre. 


\section{Bibliografía}

Aguirre Berlanga, M. (1985). Génesis legal de la revolución constitucionalista revolución y reforma. México: Talleres Gráficos de la Nación.

Ayllón González, M.E. (2010). Manual de Derecho Constitucional Mexicano. México: Porrúa.

Barceló, D. A., y Piña, J.A. (2010). Historia de las Instituciones Jurídicas. Tabasco: UNAM.

Burgoa, I. (2003). Diccionario de Derecho Constitucional, Garantías y Amparo, $7^{\mathrm{ma}}$ ed. México: Porrúa.

Cabanellas, G. (1989a). Diccionario enciclopédico de derecho usual Tomo $V, 21^{\text {a }}$ ed. Buenos Aires: Heliasta.

(1989b). Diccionario enciclopédico de derecho usual Tomo I, $21^{\mathrm{a}}$ ed. Buenos Aires: Heliasta.

(1989c). Diccionario enciclopédico de derecho usual Tomo IV, $21^{\text {a }}$ ed. Buenos Aires: Heliasta.

$21^{\text {a }}$ ed. Buenos Aires: Heliasta.

Cámara de Diputados del H. Congreso de la Unión. (2020). "Constitución Política de los Estados Unidos Mexicanos”. Cámara de Diputados del H. Congreso de la Unión. Recuperado de http://www.diputados. gob.mx/LeyesBiblio/ref/cpeum.htm

(11, marzo 2020). "Boletín No. 3463 El municipio es el origen de la voluntad popular y se debe fortalecer”. Comunicación Social Cámara de Diputados H. Congreso de la Unión. Recuperado de http://www5.diputados.gob.mx/index.php/es1/Comunicacion/ Boletines/2020/Marzo/11/3463-El-municipio-es-el-origen-de-lavoluntad-popular-y-se-debe-fortalecer-Munoz-Ledo

(12, agosto 2019). "Nota $\mathrm{N}^{\circ} .2768$ Convocan presidentes municipales de distintos estados a una reunión nacional de alcaldes el 
próximo lunes 19 de agosto en Cámara de Diputados". Comunicación Social Cámara de Diputados H. Congreso de la Unión. Recuperado de http://www5.diputados.gob.mx/index.php/es1/Comunicacion/ Agencia-de-Noticias/2019/Agosto/12/2768-Convocan-presidentesmunicipales-de-distintos-estados-a-una-reunion-nacional-dealcaldes-el-proximo-lunes-19-de-agosto-en-Camara-de-Diputados Câmara dos Deputados do Brasil (2020). "Constituição da República Federativa do Brasil". Câmara Dos Deputados do Brasil. Recuperado de https://www2.camara.leg.br/atividade-legislativa/legislacao/ constituicao 1988

Castagno, A. (1997). “Gobierno”, en M. Osorio y Florit, C. Obal, y A. Bitbol (eds.), Enciclopedia Jurídica Omeba Tomo XIII (pp.309-341). Buenos Aires: Driskill.

Castorena, J. J. (1926). El problema Municipal Mexicano. México: Editorial Cultura.

Comisión Nacional para la Celebración del Sesquicentenario de la Proclamación de la Independencia Nacional y del Cincuentenario de la Revolución Mexicana. (1960). Diario de los Debates del Congreso Constituyente 1916-1917. Tomo II. México: Talleres Gráficos de la Nación.

Congreso de la Nación Argentina. (2020). Constitución Nacional de Argentina. Congreso de la Nación Argentina. Recuperado de https:// www.congreso.gob.ar/constitucionNacional.php

Convención Constituyente de la Provincia de Buenos Aires. (1994). Constitución de la Provincia de Buenos Aires. Argentina.gob. ar. Recuperado en https://www.argentina.gob.ar/normativa/ provincial/1ey-0-123456789-0abc-defg-000-0001bvorpyel/ actualizaci $\% \mathrm{C} 3 \% \mathrm{~B} 3 \mathrm{n}$

Convención Municipal Constituyente. (1995). Carta Orgánica Municipal de la Ciudad de Córdoba. Córdoba, Argentina: Municipalidad de Córdoba. 
Corominas, J., y Pascual, J. A. (1991). Diccionario Critico Etimológico Castellano e Hispano. España: Editorial Gredos.

De la Cueva, M. (1948). "La crisis de la soberanía", en E. Trigueros Sarabia, F. G. Gaxiola, y J. M. Escalante (dirs.), Crisis del Pensamiento Político; Ciclo de Conferencias de 1946 (pp. 33-70). México: INCAM.

Del Rivero del Rivero, J. A. (1986). Reformas en 1982 al artículo 115 constitucional (tesis de licenciatura). UNAM: México.

(2017). "Análisis diacrónico de la historia constitucional mexicana: los reflejos del humanismo y las indefiniciones del sistema político", en G. Molina Carrillo (coord.), La constitución política de México en su centenario; obra conmemorativa (pp. 43-60). México: Mariel.

(octubre 2019). “Análisis diacrónico de la Constitución de Tabasco: las indefiniciones del federalismo mexicano y su impacto en el contexto local", en Universidad Juárez Autónoma de Tabasco (organizadora), Primer Centenario de la Constitución del Estado de Tabasco. Conferencia llevada a cabo en la División Académica de Ciencias Sociales y Humanidades de la Universidad Juárez Autónoma de Tabasco, México.

Diario Oficial de la Federación. (20, agosto de 1928). "Ley que reforma los artículos 73, 74, 76, 79, 89, 94, 96, 97, 98, 99, 100 y 111 de la Constitución Política de la República”. Diario Oficial de la Federación. Recuperado de http://dof.gob.mx/nota_to_imagen_fs.p hp?codnota $=4601265 \&$ fecha $=20 / 08 / 1928 \&$ cod_diario $=197559$

Díaz del Castillo, B. (1986). La verdadera Historia de la Conquista de Nueva España; Colección Sepan Cuantos No.5. México: Porrúa.

Duverger, C. (2019). Vida de Hernán Cortés. La espada. (traducción de E. Cazenave, y C. Duverger), México: Taurus. 
Elguera, A. (1997). "Municipio", en M. Ossorio y Florit, C. R. Obal, y A. Bitbol (eds.), Enciclopedia Jurídica Omeba Tomo XIX (pp. 960979). Buenos Aires: Driskill.

Fernández Sotelo, R. D. (1987). “Mito y realidad en las leyes de población de Indias", en F. de Icaza Defour (coord.), Recopilación de leyes de los reinos de las Indias (pp. 209-313). México: Miguel Ángel Porrúa. Ferrer Silva, C. (2007). "La controversia constitucional y el municipio", en M. González Oropeza y D. Cienfuegos Salgado (coords.), El municipio en México (pp. 203-220). México: Editora Laguna.

Ferrier, C. J. (2007). Paratitla o exposición compendiosa de los titulos del digesto. México: SCJN.

Gurria Lacroix, J. (1979). “José Eduardo de Cárdenas 1765-1821”, En J.

E. De Cárdenas. Memoria a favor de la Provincia de Tabasco. (pp. 513). México: Consejo Editorial del Gobierno del Estado de Tabasco. Instituto Nacional de Estudios Históricos de la Revolución Mexicana. (1985). Obras politicas de Blas Urrea. México: Talleres Gráficos de la Nación.

Kropotkin, P. (2005). Historia de la revolución francesa. España: Vergara. Levene, R. (1973). Las indias no eran colonias. Madrid: Espasa-Calpe. Levi, L. (1981). “Gobierno", en N. Bobbio, y N. Matteucci (Dirs.), Diccionario de política (pp.743-745). México: Siglo Veintiuno Editores.

Luna Arroyo, A. y Alcerraga, L.G. (1982). Diccionario de Derecho Agrario Mexicano. México: Porrúa.

López de Gómara, F. (2000). La Conquista de México. Madrid: Dastin. López Monroy, J.J. (2003). Sistema Jurídico del Common Law. México: Porrúa.

Madariaga, S. (1970). Biografía de Hernán Cortés. México: Porrúa. Mejía Pedrosa, N. (2013). 200 Años de Administración Publica en México Tomo VIII; Balance y Perspectivas del Desarrollo Municipal. México: INAP. 
Mensa, A. (2007). "El Estado municipal en Argentina". Provincia No.17, enero-junio, pp. 23-48. Recuperado de http:// biblioteca.municipios.unq.edu.ar/modules/mislibros/archivos/ elestadomunicipalmensaandrea.PDF

Muñoz Ledo, P. (agosto 2019). "Iniciativa para revertir la pirámide invertida del federalismo", en Cámara de Diputados del H. Congreso de la Unión (presidencia), Sesión de la Comisión Permanente del Congreso de la Unión. Sesión llevada a cabo en el Palacio Legislativo de San Lázaro, México. Recuperado de https://youtu.be/ Cy5GLVFPpZ8

Ortega, J. (2001). "Hacia un nuevo federalismo", en D. Valadés, y R. Gutiérrez Rivas (coords.), Economía y Constitución; Memoria del IV Congreso Nacional de Derecho Constitucional Tomo IV (pp. 191196). México: UNAM.

Pérez Luño, A. (2013). Los Derechos Fundamentales. Madrid, España: Tecnos.

Quintana Roldan, C. F. (2008). Derecho Municipal. México: Porrúa.

Rabasa, E. O. (1997). Historia de las Constituciones Mexicanas. México: UNAM.

Rodríguez Mejía, G. (2002). “Ayuntamiento”, en M. Carbonell (coord.), Enciclopedia Jurídica Mexicana I (pp.477-480). México: PorrúaUNAM.

Ruiz Massieu, J. F. (1982). El nuevo artículo 115. México: Revista de Investigaciones Jurídicas.

Sánchez de la Barquera y Arroyo, H. (2014). "El federalismo como forma de organización del Estado", en H. Sánchez de la Barquera y Arroyo (ed.), Antologías para el estudio y la enseñanza de la ciencia política. Volumen I: Fundamentos, teoría e ideas políticas (pp. 211-238). México: UNAM. 
SCJN. (1935). MUNICIPIOS, PERSONALIDAD DE LOS. Semanario Judicial de la Federación. Tomo XLV, p. 3577. Registro digital: 279296. Quinta Época.

Sotelo Inclán, J. (1943). Raiz y Razón de Zapata. México: Etnos.

Tena Ramírez, F. (1948). "La crisis de la división de poderes", en E. Trigueros Sarabia, F. G. Gaxiola, y J. M. Escalante (dirs.), Crisis del Pensamiento Político; Ciclo de Conferencias de 1946 (pp.153-181). México: INCAM.

(1976). Leyes fundamentales de México 1800-1976 séptima edición. México: Porrúa.

Valencia Carmona, S. (2002). "Derecho Municipal", en M. Carbonell (coord.), Enciclopedia Jurídica Mexicana XI (pp. 3-255). México: Porrúa-UNAM.

(2012). "Comentario al Artículo 115", en M. Carbonell (coord.), Derechos del Pueblo Mexicano; México a través de sus Constituciones Tomo $V$ (pp. 925-1055). México: H. Cámara de Diputados LXI legislatura; Senado de la Republica; SCJN; TEPJF; IFE; IIJ-UNAM; Porrúa.

(2017). El municipio mexicano: génesis, evolución y perspectivas contemporáneas. México: Secretaría de Gobernación; Secretaría de Cultura; INEHR; IIJ-UNAM.

Villanueva Gómez, L.E (2014). "La división de poderes: Teoría y realidad”, en H. Vázquez Ramos (coord.), Catedra nacional de derecho Jorge Carpizo: Reflexiones Constitucionales (pp. 149-186). México: UNAM

Zarauz López, H. L. (2016). Álvaro Obregón y la reforma a la Suprema Corte de Justicia de la Nación en el año de 1928. México: SCJN. 